\title{
LA TRANSICIÓN A LA EDAD DEL HIERRO EN EL SUROESTE PENINSULAR. EL PROBLEMA DE LOS CELTICI
}

\author{
THE TRANSITION TO IRON AGE IN THE IBERIAN \\ SOUTHWEST. THE PROBLEM OF THE CELTICI
}

\author{
por \\ JUAN AURELIO PÉREZ MACÍAS
}

RESUMEN En la Segunda Edad del Hierro una parte del suroeste ibérico fue ocupado por poblaciones de Celtici, que ofrecen un fuerte contraste con los Turdetani del Valle del Guadalquivir. Este trabajo defiende que estos Celtici penetraron en la Baeturia Celtica desde la Meseta aprovechando el despoblamiento que se documenta en la zona desde el Período Orientalizante.

\begin{abstract}
During the Second Iron Age one part of the Southwest of the Iberian Peninsula was colonized by the Celtici, who are clearly distinguishable fron the Turdetani of the Gualdalquivir Valley. This paper affirms that the Celtici penetrated the Baeturia Celtica by was of the Meseta, taking advantage of the zone'depopulation, documented since the Orientalizing Period.
\end{abstract}

Uno de los fenómenos de mayor transcendencia en la protohistoria del suroeste de la Península Ibérica es la aparición desde mediados del siglo $\mathrm{V}$ a.C. de unas poblaciones, los célticos del suroeste, sin precedentes en la Edad del Bronce de la zona y eje de su caracterización frente a hechos como la Romanización.

Parte del suroeste peninsular participará de la reactivación económico-cultural que desencadena el comercio fenicio desde la Bahía de Cádiz. La potencialidad económica de la sociedad de la Edad del Bronce, que controló los mecanismos técnicos y comerciales de la producción de plata, fue un elemento fundamental que favoreció la interacción cultural de tartessios y fenicios, como consecuencia de la cual en la II Edad del Hierro se perfiló una cultura nueva, la turdetana.

Sin embargo, el aporte cultural y comercial fenicio se dirigió exclusivamente a la zona costera del Golfo de Cádiz, costas atlánticas y algunos enclaves del interior que, por su dedicación minero-metalúrgica relacionada con la producción de plata, eran de interés preferente para su comercio. Resta por dilucidar si los materiales fenicios aparecidos en las zonas mineras indican la presencia efectiva de comerciantes fenicios o el control tartéssico, de cultura orientalizante, sobre esos territorios. Pero ésta es una cuestión que, no careciendo de interés, nos aparta de nuestra intención. De este panorama general sólo conviene 
resaltar que una parte importante del suroeste, sin un contacto directo con las culturas fenicia y tartéssicoorientalizante, tuvieron que evolucionar de manera diferente. No sabemos hasta qué momento se mantienen las poblaciones de la Edad del Bronce, ni qué cambios experimentan.

En este cuadro sí conocemos perfectamente que a partir del siglo $V$ a.C. nuevos elementos culturales hacen su aparición en la zona. Son las fuentes greco-latinas las que nos describen en el suroeste poblados de célticos (García Iglesias 1971; Tovar 1974), pero son las fuentes arqueológicas las que han permitido un mejor conocimiento de los mismos (Berrocal 1993). Estas poblaciones de celtici representan sin duda un elemento extraño a la zona, como indica fehacientemente su cultura material. Nuestra intención se centrará por ello en mostrar cómo se produjo la incorporación de estas gentes a las poblaciones asentadas en la zona, es decir, aquellas que desde época tartéssica controlaban las comarcas costeras (turdetanos) y aquellas asentadas en el interior y escasamente afectadas por el impulso orientalizante. Creo que de este modo el territorio de estos celtici y sus áreas de expansión pueden comprenderse de una manera más razonada.

Como está del todo clarificada la transición a la Edad del Hierro en la zona de asentamiento turdetano, no vamos a extendernos en ella. Baste recordar aquí los trabajos efectuados en la zona de Huelva, más intensamente excavadas que otras áreas (Belén, Fernández-Miranda y Garrido, 1977; Ruiz, Blázquez y Martín de la Cruz 1981; Fernández Jurado 1985), donde se asiste sin grandes traumas a la evolución de la cultura tartéssica a la turdetana. También nos parece oportuno destacar que ya desde el Bronce Final el territorio se encuentra estructurado en torno a unos centros hegemónicos (Huelva, Niebla y Tejada la Vieja), que perduran en época turdetana y aún en la romana (Campos y Gómez 1995).

Más nos interesa comentar esta transición en la zona ocupada posteriormente por los celtici. Esta zona de ocupación de celtici ha sido extensamente estudiada por Berrocal (1993) y no vamos a realizar un repetitivo trabajo de delimitación. Conviene resaltar, no obstante, que esta zona no sólo se reduce a la Baeturia Celtica, que, como bien ha señalado Berrocal (1995), no deja de ser sino una delimitación debida a la administración romana; entendemos pues por territorio de celtici aquel que en época prerromana ofrece un ambiente de cultura material homogéneo, netamente diferente del turdetano, con elementos arqueológicos de filiación meseteña y rasgos toponímicos del denominado tronco indoeuropeo (Berrocal 1993). Son tierras vertebradas por la línea del río Guadiana y sus tributarios, en el sur de la provincia de Badajoz, norte de la de Huelva y tierras portuguesas al sur del Tajo, con algunas excepciones que ya comentaremos. Aunque existen otras comarcas de celtici en el sur peninsular, descritas en la Naturalis Historia de C. Plinius, la preponderancia de estos elementos sobre las poblaciones anteriores no está demostrada todavía arqueológicamente, y por ello resulta problemático por ahora todo intento de conocer el peso de estos grupos en la definición cultural de esas zonas.

\section{¿EDAD DEL BRONCE O EDAD DEL HIERRO?}

Durante el Bronce Final el suroeste peninsular muestra una variedad cultural que no puede ser definida estrictamente como tartéssica. Si bien los estudios sobre el fenómeno tartéssico son todavía la estrella guía que ilumina la investigación sobre esta etapa, trabajos más puntuales han demostrado la regionalización a la que se asiste en este período en función del medio físico y la caracterización económica (Gómez Toscano 1997).

Alejándonos del foco tartéssico de Bajo Guadalquivir, que desemboca finalmente, como hemos expuesto, en la cultura turdetana, el Bronce Final del suroeste está lejos de esa caracterización. Hace ya algunos años dábamos a conocer algunos poblados del Bronce Final en la zona serrana del norte de Huelva, y su cultura material ofrecía peculiaridades que los alejaban de lo tartéssico, a pesar de participar de las generalidades propias del Bronce Final del sur peninsular (Pérez Macías 1985). Esta comarca, definida en lo físico por 
su conexión a la red hidrográfica del río Guadiana, tampoco era uniforme. En ella distinguimos las zonas de Rivera del Chanza y la de Rivera del Múrtiga.

De los yacimientos localizados en la Rivera del Múrtiga sobresalía el asentamiento de la Sierra de la Lapa (Encinasola), situado en la confluencia del Arroyo de Valquemado y la Rivera del Múrtiga, sobre un espolón de la Sierra de la Lapa, lo que lo define como un poblado de altura. Aparte de esa situación estratégica desde una altura dominante, el carácter más destacado de ese poblado se apoyaba en su situación cercana a los filones de sulfuros de cobre de la corrida filoniana del Múrtiga (Jubes y Carbonell 1920). La explotación de estas mineralizaciones, o más concretamente de los carbonatos de cobre superficiales de estos criaderos, se corroboró por la aparición de martillos de minero con surco central de enmangue (Gonzalo y Tarin 1886) y por las escorias de cobre encontradas en el poblado (Pérez Macías 1996).

Otro aspecto interesante se deduce del estudio de las cerámicas de superficie de este poblado, cuya tipología muestra formas más antiguas que las que se hacen corrientes a partir de la denominada fase I del Cabezo de San Pedro (Ruiz Mata 1979). Predominan las cazuelas bruñidas de carena alta acusada y borde entrante, los vasos bicónicos de gollete desarrollado, y las cazuelas de hombro escalonado. Entre las vasijas de almacenaje la forma más abundante es el vaso de carena alta y borde cóncavo corto inclinado al interior, con paralelos en el Bronce Final Antiguo de la estratigrafía de la Mesa de Setefilla (Aubet, Serna, Escacena y Ruiz 1983) y Montoro (Martín de la Cruz 1987).

En consecuencia, de manera provisional hemos datado este hábitat en los siglos X y IX a.C. Su dedicación económica volcada a la producción de cobre refuerza su antigüedad, puesto que a partir de las primeras manifestaciones del comercio fenicio parece ser que esta producción metálica desapareció en aras del monopolio minero-metalúrgico sobre los minerales argentíferos, verdadero interés del comercio fenicio en la zona (Pérez Macías 1996).

Fue probablemente este cambio en los vectores económicos lo que originó el abandono del yacimiento de la Sierra de la Lapa, aún antes del fuerte desarrollo de la minería de la plata como consecuencia del comercio fenicio. No puede pensarse que fuera el comercio fenicio el responsable último de este traslado de la población, sino el cambio experimentado por la economía de los poblados tartéssicos del Bajo Guadalquivir, que a partir del siglo IX a.C. se fueron especializando cada vez más en el comercio con los minerales argentíferos y en la producción de plata (Huelva, San Bartolomé de Almonte, Niebla, etc).

Este relato de la evolución de los poblados de Bronce Final de la zona se complica todavía más porque no hemos encontrado síntomas claros de que el sistema de poblamiento continuara con la misma pujanza que se observa en la Sierra de la Lapa. Es decir, carecemos de hábitats del Bronce Final en los que se encuentren elementos de comercio fenicio que nos indiquen que simplemente la población cambiaría el patrón de asentamiento al perder peso las anteriores estrategias, supeditadas al aprovechamiento de los yacimientos de sulfuros de cobre con carbonatos de cobre superficiales. Por ello, en otra ocasión hemos planteado una drástica crisis demográfica en toda la zona del Múrtiga (Pérez Macías 1985), cuyas poblaciones mineras pudieron sentirse atraídas por el gran auge que se produjo en toda la Faja Piritífera (Andévalo) y en los asentamientos tartéssicos de la Tierra Llana (Ruiz y Pérez 1989).

Aunque no creíamos en un despoblamiento total, últimos descubrimientos nos hacen matizar este panorama. El poblamiento no tendría ya la envergadura y extensión del hábitat de la Sierra de la Lapa, pero hemos encontrado pequeños asentamientos de altura, de corta ocupación según el registro cerámico recogido en superficie, en los que hacen acto de presencia los productos fenicios, especialmente ánforas. Ya no se encuentran situados sobre los filones de minerales de cobre, sino en lugares estratégicos de paso, donde el paisaje sólo ofrecía posibilidades económicas relacionadas con una ganadería y agricultura de subsistencia. Entre estos yacimientos pueden citarse el poblado de Sierra Menjuana (Cumbres Mayores), sobre el Puerto de los Arriscaderos, la vía de comunicación entre la Sierra de Huelva y la Baja Extremadura, y el Cerro de los Monos (Jerez de los Caballeros). Sus cronologías pueden alargarse al siglo VI a.C., con lo cual este 
minimum poblacional se haría más acusado en el Bronce Final Orientalizante. Describirlos exactamente como los primeros poblados de la Edad del Hierro parece exagerado habida cuenta que si exceptuamos el conocimiento probable del hierro y las ánforas fenicias a torno, su cultura debería mantenerse todavía fuertemente enraizada en la Edad del Bronce. La aculturación y sus consecuencias afectarían muy poco a estas poblaciones serranas.

Otra comarca bien definida de la Sierra de Huelva, los Picos de Aroche, ha ofrecido también yacimientos para conocer la evolución de los asentamientos a fines de la Edad del Bronce. Su originalidad estriba en las diferencias con los poblados de la Rivera del Múrtiga, con cultura material encuadrable en el Bronce Final Meridional, mientras estos poblados de Aroche presentan mucha semejanza con el Bronce Final Portugués.

Lo característico de los poblados de la Rivera del Chanza (Picos de Aroche) son las decoraciones bruñidas al exterior de los vasos, conocidas desde hace años en los poblados del estuario del Tajo y Sado (Cunha Serrao 1970) y poco frecuentes en el Bajo Guadalquivir. Un yacimiento paradigmático es el Cerro del Castillo (Aroche), situado en altura, con vasos de provisiones de carena alta y borde cóncavo inclinado al interior, las cazuelas carenadas de perfil anguloso y los carretes con baquetón central (Pérez Macías 1985). Más próximo a la unión del Chanza con el Guadiana es el yacimiento de los Riscos del Castillo (Cabezas Rubias), donde se documenta también la cerámica decorada con motivos bruñidos al exterior, las cazuelas de carenas altas y borde saliente o las cazuelas de carena alta y borde inclinado al interior; la proporción de los cuencos peraltados es abundante en comparación con otros yacimientos del Bronce Final del sur peninsular (Pérez Macías 1990). Existen pocos elementos de datación fiables para situar correctamente estos yacimientos, salvo el carrete del Cerro del Castillo de Aroche, cuyos paralelos tipológicos se encuentran sólo en la fase prefenicia del ámbito tartéssico (Pérez Macías 1985). Carecen también de otras especies autóctonas del repertorio tartéssico orientalizante, como las cerámicas con decoración de digitaciones, lo que nos permite intuir que estos poblados no sobrepasan, como sucedía en la Rivera del Múrtiga, los primeros decenios del siglo VIII a.C.

En el yacimiento del Alto del Cinchato (Ruiz y Pérez 1989) se puede afirmar que el asentamiento correspondería al siglo VII a.C. Un gran vaso de almacenaje de carena alta y largo cuello cóncavo sólo encuentra paralelos en las fases de Bronce Final Orientalizante del Bajo Guadalquivir (Ruiz Mata 1995; Pellicer 1989).

Las tónicas de poblamiento en todos estos poblados se mantuvo invariable a lo largo del tiempo, y no se abandonaron los asentamiento en altura. Su economía hubo de estar supeditada a la ganadería y, en menor medida, a la agricultura y la caza, pues no se conocen yacimientos mineros en las inmediaciones, ni en registro de superficie existen evidencias de actividades metalúrgicas (escorias, minerales, etc).

Por ello, nos encontramos con que tampoco en la Rivera del Chanza se produjo una continuidad de los asentamientos en la Edad del Hierro. Aunque algunos continúen en el Bronce Final Orientalizante, todos se abandonan antes de que se produzca el cambio cultural. Sin que sepamos por qué, la barrera de esta falta de yacimientos puede situarse como mucho en el siglo VII a.C., a partir del cual no hemos encontrado evidencias firmes de poblamiento.

Otra de las comarcas naturales de esta parte de la provincia de Huelva es la Sierra de Aracena, con mayores altitudes y una red hidrográfica más abundante y caudalosa. La ocupación del Bronce Final se establece tanto al aire libre como en cuevas, algunas de ellas habitadas desde el Neolítico.

Dentro de los hábitats al aire libre destacan el Cerro de San Cristóbal (Almonaster la Real) y El Trastejón (Zufre), este último el único yacimiento del Bronce Final excavado en toda la zona. El Cerro de San Cristóbal es un yacimiento de altura con gran capacidad de control visual, pues se asienta sobre una de las cumbres de mayor altitud de la provincia de Huelva. Los materiales muestran una tipología característica del Bronce Final Meridional, pero, a diferencia de los yacimientos tartéssicos, faltan las especies de retícula bruñida y la cerámica pintada (Pérez y Buero 1986). Algunas formas y la aparición de galbos con decoraciones 
digitales colocarían este yacimiento en el siglo VIII a.C. y, quizás, los inicios del siglo VII a.C. Es un yacimięnto en el que tampoco existen evidencias de actividades mineras o metalúrgicas.

La ocupación del Bronce Final de El Trastejón se superpone a otra del Bronce Pleno. Sus formas son también las comunes para el Bronce Final Meridional, aunque no aparecen tampoco las especies de retícula bruñida ni la de motivos pintados. Su cronología ha sido establecida claramente en momentos prefenicios, tanto por la tipología de los vasos como por los análisis radiométricos (Hurtado y García 1994).

El hábitat en cuevas ofrece unas especificidades que deben estar en relación con la prolongada ocupación de las mismas desde el Neolítico. El núcleo más importante es el de la Peña de Arias Montano, donde se encuentran los únicos elementos orientalizantes de toda la zona (cerámicas grises y ánforas), que en algún caso apoyan una extensión del poblamiento hasta el siglo V a.C. (Pérez Macías 1986; Gómez, Álvarez y Borja 1990).

Como recapitulación de los datos conocidos sobre el Bronce Final en la Sierra de Huelva, merece destacarse el carácter marginal de estos poblados, escasamente relacionados comercialmente con el ámbito tartéssico, y su patrón de asentamiento disperso, siempre en posiciones de altura en las cercanías de pasos naturales. La falta de evidencias fenicias y sus tipologías cerámicas prefenicias nos muestran que toda la zona sufriría un lento receso demográfico a partir, sobre todo, del siglo VIII a.C. A partir de este momento y en todo el período orientalizante perviven muy pocos asentamientos (Sierra Menjuana, Peña de Arias Montano, etc), y cuando lo hacen son de corta duración. Esta situación contrasta fuertemente con la consolidación de unos centros hegemónicos en la Tierra llana de Huelva (Huelva, Niebla, y Tejada la Vieja) que vertebran todo el territorio (Campos y Gómez 1995).

A grandes rasgos también es suficientemente conocido el Bronce Final del sur de Portugal. En el Bajo Alentejo destacan el poblado de Outeiro do Circo (Beringel, Beja) y el Cerro dos Castelos de Sao Bras (Serpa, Beja).

El Cerro de Outeiro do Circo entra dentro de la tónica de los poblados de Bronce Final del suroeste peninsular, con cerámicas con motivos bruñidos al exterior de los vasos, alguna cerámica pintada, y formas de carena alta y borde cóncavo saliente. Son también abundantes, como en los poblados de la zona de Aroche, los cuencos ovoides y globulares. Su cronología se ha situado entre el siglo X y el VII a.C. (Parreira 1975), pero de lo que no cabe duda es de que a juzgar por la falta de cerámicas a torno el poblado se mantuvo sin ninguna influencia orientalizante. Es pues otro asentamiento que demuestra el abandono del sistema de poblamiento en los siglos VIII y VII a.C.

En el caso del Cerro dos Castelos de Sao Bras se suceden dos ocupaciones, una primera de la Edad del Cobre y otra del Bronce Final. Dentro de la ocupación del Bronce Final se repite el elenco cerámico de los poblados del Bronce Final del suroeste: motivos bruñidos en el exterior de los vasos, cazuelas de carena alta y gran abundancia de cuencos. El momento final de este poblado, sin cerámicas a torno, puede establecerse de manera provisional en los siglos VIII y VII a.C. (Parreira 1983).

Se conocen otros poblados del Bronce Final en el distrito de Beja, como Passo Alto (Monge Soares 1992), Rathinos (Fragoso da Lima, 1960), Mangancha (Domergue y Andrade 1971), etc, y sus cronologías confirman la ruptura los patrones de asentamientos entre el Bronce Final y el Período Orientalizante.

Los únicos vestigios de continuidad del hábitat durante el período orientalizante aparecen en los poblados de la línea del Guadiana. Este es el caso de Mértola (Rego, Guerrero y Gómez 1996), Azougada (Varela 1990) y Castelo Velho de Safara (Monge, Fatima y Peixoto 1985; Almagro-Gorbea 1979). Son todos ellos lugares de gran interés para el comercio fenicio, que se extiende a través de esta vía hacia la Extremadura española. Como hemos comentado, fuera de esta línea de penetración del comercio fenicio, el sistema de poblamiento sucumbió probablemente por la reorganización que impuso, sin pretenderlo, el intercambio fenicio. Puede sostenerse, no obstante, que la Primera Edad del Hierro supuso, al menos, un cambio en el patrón de los asentamientos. 
En el Alto Alentejo el poblado del Bronce Final mejor conocido es Coroa do Frade (Morais Arnaud 1979), un asentamiento interesante desde el punto de vista cronológico, pues dentro de un conjunto cerámico a mano característico del Bronce Final aparece una fíbula de doble resorte. En todos los yacimientos que venimos analizando, la inexistencia de cerámicas a torno podría haberse utilizado para fecharlos en momentos anteriores al período orientalizante. Este poblado advierte, de este modo, que el comercio fenicio tuvo unos cauces de difusión específicos, que no estuvo presente en todos los yacimientos del suroeste ibérico. Por tanto, con las debidas reservas que impone la tipología, hemos situado a la mayor parte de ellos en los siglos VIII y VII a.C., pues la no aparición de cerámicas fenicias no es una condición que indica una cronología anterior al Orientalizante. De todas formas, es evidente que el poblado de Coroa do Frade ofrece idéntico panorama que la mayor parte de los asentamientos anteriores y no se advierten huellas de poblamiento posteriores al siglo VII a.C.

Este asunto es aún más grave en el Alentejo, pues ya no se trata de simples poblados abiertos, como los conocidos en la Sierra de Aroche, sino de grandes poblados amurallados (Outeiro do Circo y Coroa do Frade), similares a los de la Sierra de Aracena (Papúa y Trastejón).

En la costa del Alentejo el Bronce Final es conocido a través del poblado de Cerradinha, quizás de una cronología anterior, según se denota de las decoraciones tipo Cogotas y del perfil de las cazuelas (Tavares y Soares 1978), características del Bronce Tardío y de los inicios del Bronce Final. Por lo demás, salvo la presencia de asentamientos fenicios cercanos en el estuario del Sado (Mayet y Tavares 1992; Soares y Tavares 1986), establecimientos comerciales de cara a los poblados del interior, el poblamiento del Bronce Final es poco conocido.

Este mismo fenómeno vuelve a repetirse en la parte meridional de la provincia de Badajoz. Desde el estudio pionero de M. Almagro Gorbea (1977) se observaba la puntual localización de los yacimientos de la Primera Edad del Hierro (Período Orientalizante), de la que el poblado y la necrópolis de Medellín es su ejemplo más significativo. La pujanza del Bronce Final de la zona se intuía no por el número de poblados, sino por la riqueza de algunos tesoros, como el de Bodonal de la Sierra.

Desde ese momento poco es lo que se ha avanzado, salvo el meritorio intento de Enríquez Navascués por sistematizar las últimas novedades sobre hallazgos de superficie (Enríquez 1990).

Dentro del relativamente numeroso grupo de poblados de la línea del Guadiana (Los Corvos, La Oliva, Atalaya de Zarza y Castillo de Alange), son de especial significación los conjuntos cerámicos de Atalaya de Zarza y Castillo de Alange. El primero de ellos es evidente que corresponde a una ocupación de los momentos antiguos del Bronce Final, pues no se presenta ningún tipo de elementos más tardíos de época orientalizante. El Castillo de Alange, ya excavado y publicado (Pavón 1994), sirvió como asentamiento de una comunidad de la Edad del Bronce hasta los momentos iniciales del Bronce Final, en los que se pierden las huellas de todo poblamiento; explica perfectamente el problema que venimos defendiendo, pues un poblado con casi un milenio de ocupación ininterrumpida desde los comienzos de la Edad del Bronce se abandona precisamente en época orientalizante o incluso en un momento ligeramente anterior.

Mayor significación tiene para nosotros, por su proximidad a la zona que estamos estudiando, el poblado de la Sierra de Martela. Aunque sus excavadores plantean una ocupación desde el siglo VI al III a.C. (Enríquez y Rodríguez 1988), desde nuestro punto de vista no existe continuidad del hábitat entre los materiales del Bronce Final, que cabría situarlo, como se señala en pleno siglo VII a.C., y los materiales de la Segunda Edad del Hierro, que no pueden ser considerados anteriores a fines del siglo IV a.C. Faltan por completo materiales orientalizantes, a pesar de que por la tipología cerámica de la Edad del Bronce podamos establecer que el poblado se mantuvo en el momento de esplendor del comercio fenicio en el suroeste (siglo VII a.C.). Es este poblado, pues, otro punto donde queda constancia del escaso interés del comercio fenicio por estas tierras del interior. La influencia de la orfebrería fenicia sólo se dejaría sentir en el siglo IV a.C. según nos indica la cronología postorientalizante del tesorillo áureo (Berrocal 1989b). 
En resumen, el panorama de la provincia de Badajoz mantiene las constantes de poblamiento detectadas en la Sierra de Huelva y en el Alentejo, es decir, la desmembración del sistema de poblamiento a partir de la Primera Edad del Hierro (Período Orientalizante), con un descenso brusco del número de yacimientos, Sólo se mantienen algunos, como el ya citado de Medellín, lugar de paso del comercio fenicio hacia tierras del interior, verdadero centro hegemónico de toda la cuenca media del río Guadiana, donde el auge comercial propiciaría el establecimiento de instituciones plenamente urbanas (control del territorio, jerarquización como modelo político, etc).

\section{LA SEGUNDA EDAD DEL HIERRO COMO RUPTURA}

Este análisis del poblamiento durante el primer cuarto del primer milenio a.C. en el suroeste peninsular se ha realizado para compararlo con lo que sucede a partir de la segunda mitad de este milenio. De lo expuesto. en líneas precedentes cabría deducir con respecto al nivel de los asentamientos que en la mayor parte de los casos se interrumpe el sistema de poblamiento, se abandonan los poblados que surgieron alrededor del cambio de milenio y aun aquellos de más larga ocupación, como los que se iniciaron en el Bronce Pleno. A esta norma general, que encuentra reflejo sobre todo en la ausencia de materiales fenicios, escapan algunos asentamientos especialmente situados desde el punto de vista de la red comercial del circuito fenicio-tartéssico. Este es el caso de Mértola, Alcoçer do Sal, Medellín, Safara, Azougada, etc., donde el hábitat se mantiene incluso hasta época romana.

Un aspecto importante de discusión sobre la caída demográfica se refiere a la reflexión sobre si la carencia de materiales fenicios indica con seguridad el cambio de hábitats, o si, por el contrario, estamos ante poblaciones escasamente desarrolladas económicamente para que el comercio fenicio se hiciera patente en ellas. Desde este punto de vista, estas dos circunstancias son el origen de esta pérdida de poblamiento. Evidentemente, no estamos ante comunidades de la capacidad productora de las del Bajo Guadalquivir, y no existen en su territorio las mineralizaciones de plomo-plata que hubieran favorecido, como en el Andévalo onubense (Cinturón Ibérico de Piritas-Faixa Piritosa), la presencia del comercio fenicio-tartéssico, exclusivamente dirigido hacia los centros productores de plata (Pérez Macías 1996). Por ello no es extraño la ausencia de materiales arqueológicos que corroboren este comercio. Pero, por otra parte, hoy conocemos ya la evolución de la cultura material de las poblaciones autóctonas durante la Edad del Hierro, que no cesan hasta la formación de la fase turdetana (Ruiz Mata 1995; Pellicer 1989). Estos materiales del Bronce Final Orientalizante no aparecen ni en los poblados que hemos considerado que se abandonan, ni en otros que podrían haber sido sus sucesores con el cambio de los asentamientos. Creemos, en definitiva, que se asiste en todo el suroeste a una bajada significativa del índice demográfico. A falta de excavaciones, sus causas se nos escapan por ahora, aunque no por ello queremos dejar de señalar su posible relación con la demanda fenicia y la centralización de este comercio y producción en determinadas zonas del suroeste, especialmente puertos fluviales, puertos marítimos y zonas de producción minera.

La migración de estas poblaciones a esas zonas, en busca de mayores expectativas económicas generadas por la demanda metiterránea, es la única solución lógica para explicar este drástico descenso del número de poblados, aunque desgraciadamente no existen datos arqueológicos fiables que lo confirmen. De todos modos, no es este aspecto el que queremos defender, sino únicamente la crisis demográfica, que sí está suficientemente constatada en nuestra exposición sobre el poblamiento del Bronce Final en el Suroeste.

Desde los momentos iniciales de la Segunda Edad del Hierro asistiremos en todo el suroeste a la presencia de poblaciones con una cultura totalmente nueva y sin ninguna relación con el Bronce Final de la zona. Estas poblaciones, no homogéneas en su composición, formaron una cultura que los escritores de época romana (Polibio, Estrabón, Plinio y Pomponio Mela) denominaron "céltica", profundamente diferenciada 
de la que se desarrolla a orillas del Baetis y en los enclave costeros del mediodía peninsular. La posterior administración romana las incluyó en la Baeturia Celtica, dependiente de la Hispania Ulterior (Hispania Ulterior Baetica), y en los pueblos célticos de la Lusitania (Hispania Ulterior Lusitania). La arqueología (Berrocal 1993) ha comprobado que, al menos en la cultura material, poseen unas características comunes, que ayuda a definir a los pueblos célticos del suroeste peninsular. Optamos por este término porque nos parece enteramente satisfactoria la explicación de (Berrocal 1995) sobre las características comunes de estos pueblos, sólo separados por los límites de la posterior administración romana.

Conscientemente, hemos indicado que estos pueblos representan una cultura nueva, sin relación con las poblaciones del Bronce Final que hemos descrito. Pero esta distinción nos lleva a exponer un problema no menor: si estas poblaciones no pueden relacionarse con las poblaciones de la Edad del Bronce, cuáles son sus orígenes más inmediatos.

En un trabajo anterior hemos intentado poner orden a los datos sobre los orígenes de la Baeturia Celtica en la Sierra de Huelva (Pérez Macías 1993b), y, aunque de manera general, hemos planteado que estos celtici son una población extraña a la zona, hemos planteado sus posibles orígenes siguiendo trabajos anteriores de Berrocal Rangel y Rodríguez Díaz (1988), y hemos establecido una posible evolución a partir de los distintos poblados y sus paralelos más cercanos.

En relación con esta cuestión, paralelamente se publicó el amplio trabajo de Berrocal Rangel (1993), en el que se hace hincapié, entre otros aspectos interesantes, en las fases de desarrollo de esta cultura. Este es un punto de divergencia de nuestras opiniones, pues mientras él defiende en cierta forma la relativa homogeneidad de esta cultura, hemos detectado que tal homogeneidad no puede sostenerse, al menos, para sus momentos iniciales. Nos parece fundamental el conocimiento de un poblado como el de Castañuelo (Aracena, Huelva), que aporta algunas claves para esclarecer este problema (Pérez y Gómez, e.p.).

Sobre la herencia puramente tartéssica surge in continuum en el Bajo Guadalquivir la cultura turdetana, sin que se pueda detectar, tal como han señalado algunos autores (Escacena 1989), signos de cambio en la evolución de estos pueblos prerromanos. Son la herencia de lo tartéssico (Bronce Final), matizado por la influencia semita, fundamentalmente gaditana (Aubet 1987), y griega (Schepton 1982).

La cultura turdetana en Huelva, perfectamente definida desde el Bronce Final en su territorio (Campos y Gómez 1995) y socio-económicamente en su fase ibérica (Ruiz y Molinos 1993), es un elemento de contraste más con las poblaciones de celtici de la ribera baja del río Guadiana.

Por el contrario, estos pueblos de celtici no encuentran relación con las poblaciones autóctonas del Bronce Final, y aun en el caso de que parte de esta población de la Edad del Bronce fuera absorbida por estas nuevas poblaciones de la Meseta, su cultura fue totalmente suplantada por la de esos nuevos pobladores. Tal sucede, entre otras cuestiones, con la lengua y las tradiciones, emparentadas con la Iberia Céltica (Tovar, 1974).

Berrocal (1993) plantea que la celtización del suroeste es un fenómeno lento en el tiempo, iniciado desde el Bronce Final por las influencias atlánticas y que cristaliza hacia la mitad del I milenio a. C. con la definición de la Baeturia Celtica. Desde este punto de vista, no sería necesario plantear la migración y asentamiento de gentes desde la Meseta, pero está por ver en primer lugar que la influencia atlántica sea efectivamente una indoeuropeización de la población, y en segundo que la presencia de material atlántico en algunos de los asentamientos suponga una verdadera influencia cultural. En aquellos puntos donde se detecta mayor incidencia atlántica, como el caso conocido de la Ría de Huelva (Almagro Basch 1939; Ruiz-Gálvez 1995), esta influencia cultural, si la hubo, desaparece totalmente como elemento de definición de la cultura turdetana. Más difícil sería por ello que se hubiera mantenido en zonas como la que venimos describiendo, en la que no cuajó siquiera la influencia fenicia, de fuerte implantación en todos los puntos de comercio.

Me parece más acertado el planteamiento de A. Canto (1995), quien establece el surgimiento de esta cultura por penetraciones de celtici desde la Meseta. Su postura le obliga a defender unas causas para estos asentamientos, y cree que la solución pudiera estar en la atracción económica de las mineralizaciones de 
hierro de la zona. Conviene señalar, sin embargo, que no todo el suroeste es una zona minera. Es decir, si hemos considerado que el problema de los celtici no es exclusivo de lo que denominamos Baeturia Celtica, sino la zona comprendida entre el sur del Tajo y en ambas riberas del río Guadiana, tal atracción no sería el detonante último, pues las mineralizaciones se encuentran sólo en las zonas Ossa Morena y Subportuguesa (Cinturón Ibérico de Piritas). Es más, conocemos asentamientos de celtici en la zona Ossa Morena en los que se han hallado pruebas del trabajo con minerales de hierro (Berrocal 1993), pero en los poblados mineros del Cinturón Ibérico de Piritas no se ha encontrado hasta ahora la menor huella de estas poblaciones de celtici, sino poblaciones turdetanas con fuerte influencia gaditano-cartaginesa (Pérez Macías 1996).

A esto hay que sumar que las mineralizaciones de la zona Ossa Morena son de carácter filoniano, y por tanto de escasa envergadura, mientras en el Cinturón Ibérico de Piritas existen numerosos y grandes depósitos de minerales que oxidan en los niveles superficiales en enormes monteras de gossan (óxido e hidróxido de hierro). ¿Cómo entonces no se establecieron estos celtici sobre estos depósitos minerales, la mayoría de los cuales se abandonaron en el siglo V a.C (Pérez Macías 1996)?

No consideramos así que sea la metalurgia del hierro una solución enteramente satisfactoria. Está atestiguada la producción de hierro en estas poblaciones (Berrocal 1993), pero los niveles de producción, de escala doméstica y para el autoconsumo según el volumen de los escoriales, contradicen que el origen del poblamiento haya que relacionarlo directamente con la producción de hierro, incluso en aquellos poblados situados en las cercanías de mineralizaciones.

Estimo que las causas de estos establecimientos debieron ser múltiples y, bajo mi punto de vista, una de las más importantes la crisis demográfica en que se encontraba la zona desde el siglo VII a.C.

Este es un hecho que encuentra reflejo en el propio análisis del sistema de poblamiento prerromano de toda la zona. Dentro de los asentamientos prerromanos del suroeste se distinguen con facilidad aquellos en los que la presencia de estos celtici fue la más característica. Corresponden a poblados que como norma general se inician en el siglo IV a.C. (Capote, Alcazaba de Badajoz, Ermita de Belén y Pasada del Abad), e incluso en la segunda mitad del siglo V a.C. (Castañuelo), en los que no se ha detectado precedentes o continuidad del poblamiento desde el Bronce Final o el Período orientalizante. Son estos poblados los que han caracterizado la cultura material de estas poblaciones de célticos como modelo diferenciado de las vecinas poblaciones turdetanas y túrdulas. Podemos considerarlos enclaves en los que el predominio de celtici fue mayoritario, pero existen también en el suroeste toda una serie de poblados ocupados desde el Bronce Final o la etapa orientalizante, como Setubal, Mértola, Azougada y Medellín entre los más conocidos, en los que esa cultura material prerromana tiene escaso paralelismo con las poblaciones celtici y unas semejanzas más acusadas con la cultura turdetana. Se encuentran enclavados en pleno territorio de extensión de los célticos del suroeste, y algunas de ellos ostentan nombres claramente ligados al fenómeno indoeuropeo (Caetobriga, Lacobriga, etc) como síntoma de la imposición de grupos célticos.

Estos dos modelos podrían responder a dos formas diferentes de asentamiento de las poblaciones célticas en el suroeste, una primera, la más generalizada, que ocupa tierras prácticamente desiertas por un fenómeno creciente de despoblamiento desde el siglo VII a.C., y una segunda que se establece en lugares donde se mantuvo población en momentos postorientalizantes, pero en las que el peso de los célticos no es tan evidente en la cultura material como en otros rasgos. También pudo ocurrir que las poblaciones orientalizantes consiguieran dominar la penetración de los célticos y por ello su cultura sea parangonable por tanto a la turdetana. Este caso pudo ser el mismo que el que traslucen los denominados túrdulos. Mezclas de pueblos en suma que haría difícil la descripción de los primeros geógrafos e historiadores de época romana.

De la relación de ciudades de la Baeturia Celtica de Plinio puede extraerse también la penetración de estas poblaciones hacia las orillas del Baetis y las serranías de Cádiz y Ronda (García Iglesias 1971; Canto 1995). Ello indicaría que estas poblaciones no se limitaron a ocupar las zonas mineras del suroeste, sino que sus movimientos pretendieron alcanzar las partes más meridionales de la Península Ibérica, como sucedió 
en efecto en la costa atlántica portuguesa. Conocer por qué no ocurrió así pudiera ser una vía de explicación a determinados rasgos del poblamiento en el suroeste.

En el caso que conocemos, la provincia de Huelva, la zona más cercana a la costa estaba habitada por turdetanos, con oppida importantes como Huelva, Niebla, Tejada la Vieja, Mesa del Castillo y Cerro de la Matanza (Guerrero, Campos y Pérez, e.p.). En esta zona, de una importancia capital de cara a las comunicaciones Este-Oeste desde el período tartéssico, no lograron establecerse los celtici, y la razón a ello hay que buscarla en el desarrollo de estructuras puramente urbanas (Bendala 1989; Campos y Gómez,1995) y la perfecta jerarquización del territorio para su defensa tanto ante problemas externos como ante posibles alteraciones del sistema de producción aristocrático de los principes y reguli turdetanos (Ruiz y Molinos 1993). En definitiva, a los célticos les fue imposible establecerse en la zona, pues frente a las comarcas serranas, con un poblamiento muy disperso anclado todavía en las tradiciones de la Edad del Bronce y con escasa incidencia de lo orientalizante, se encontraron con un territorio estructurado. Pero llegaron a intentarlo estos célticos?

Así como otros autores han señalado que la presencia de estas poblaciones pudiera estar en relación con algunas destrucciones y cortos intervalos de crisis en el mundo ibero-turdetano de fines del siglo V a.C. (Bendala 1991; Blanco 1987), en la campiña onubense ciertos hechos pueden corroborarlo. El más significativo y conocido es el abandono de Tejada la Vieja (Fernández Jurado 1989) y Cerro de la Matanza (Guerrero 1996), y la concentración de estas poblaciones en el nuevo yacimiento de Tejada la Nueva. La importancia estratégica de esta nueva población en relación a la penetración en el Bajo Guadalquivir desde la Baeturia vuelve a manifestarse en el siglo II a.C. con motivo de las Guerras Lusitanas (Canto,1975; Vidal 1996).

Idéntica preocupación defensiva se deja notar en la reparación de la muralla protohistórica de Niebla, que es reconstruida con un muro de casamatas y un bastión con basamento de sillares ciclópeos (Droop 1925; Pérez y Bedia 1996). La influencia púnico-gaditana de esta construcción también indicaría el auxilio de Gadir, especialmente interesada en el mantenimiento de sus circuitos económicos.

En la marca minera del Cinturón Ibérico de Piritas cesan su explotación los centros de Riotinto y Tharsis, pero no se observan rastros de asentamientos de célticos. Sólo Riotinto vuelve a explotarse por el interés púnico-gaditano en la segunda mitad del siglo III a.C. (Pérez Macías 1996). Esta política cartaginesa por controlar el abastecimiento de plata desde Riotinto quizás explique el fortalecimiento de una ruta hacia Gadir con puntos intermedios en Iptuci (Tejada la Nueva) y Aznalcázar (Olontigi), ambas con amonedaciones con leyendas púnicas (García y Bellido 1993). No descartamos pues la ayuda gaditana para impedir estas incursiones y asentamiento de célticos en la campiña de Huelva.

\section{CONCLUSIONES}

Con estas reflexiones sobre los asentamientos y sistema de poblamiento en el suroeste peninsular durante el primer milenio a.C., hemos pretendido destacar que, así como no existen disfunciones en el paso de lo tartéssico a lo turdetano, en el área ocupada por los denominados pueblos célticos se advierten unas peculiaridades que dan sentido a la presencia de estas poblaciones y al proceso de contacto con los pueblos prerromanos.

La llegada de estas poblaciones célticas, emparentadas con los Campos de Urnas Tardíos y los pueblos protoceltibéricos, debe estar motivada por la expansión de los pueblos celtibéricos.

Puede mantenerse que durante el Bronce Final Orientalizante se detecta una profunda disminución de los asentamientos, que pudo estar en conexión con el auge comercial de la orla costera y zona minera. Y por otro lado, que se advierte el asentamiento de poblaciones célticas sobre lugares sin elementos de ocupación anterior. Planteamos por tanto una posible vía de solución al origen de estas penetraciones en el vacío demográfico y la atracción de los focos turdetanos y túrdulos de las tierras bajas. 
Sobre algunos asentamientos que continuaron habitados durante el período orientalizante, el establecimiento de estos célticos pudo realizarse de una manera traumática bajo la forma de pequeños grupos guerreros que dominaron a la población anterior.

La penetración de estas gentes de la Meseta hacia el Valle del Guadalquivir y la Baja Andalucía (Turdetania) pudo evitarse gracias a la mejor organización política de estas sociedades, al control del territorio por las oligarquías locales y a la ayuda técnica de la llamada liga púnico-gaditana. En la zonas montañosas del interior, con escasa población dispersa en pequeños poblados de altura, el elemento céltico no encontraría la menor resistencia para su establecimiento.

La vocación de estas poblaciones por establecerse en el Valle del Guadalquivir está atestiguada en las fuentes greco-latinas y en el repetido intento de las poblaciones baeturias por penetrar en el mismo hasta los primeros momentos de la Romanización.

\section{BIBLIOGRAFÍA}

ALMAGRO, M. (1939):" El hallazgo de la Ría de Huelva y el final de la Edad del Bronce en el occidente de Europa". Ampurias 2.

(1979):" Los orígenes de la toréutica ibérica". Trabajos de Prehistoria 36.

ALMAGRO-GORBEA, M. (1977): El Bronce Final y el período Orientalizante en Extremadura. (Biblioteca Prehistórica Hispana, XV). Madrid.

AUBET, M.E. (1987). Tiro y las colonias fenicias de Occidente. Barcelona.

AUBET, M. E., SERNA, M.R., ESCACENA, J.L.y RUIZ, M.M.(1983): La Mesa de Setefilla. (Excavaciones Arqueológicas en España, 122). Madrid.

BELÉN, M., FERNÁNDEZ-MIRANDA, M. y GARRIDO, J.P.(1977):”'Los orígenes de Huelva. Excavaciones en los Cabezos de San Pedro y la Esperanza". Huelva Arqueológica III.

BENDALA, M. (1989):" La génesis de la estructura urbana en la España antigua". Cuadernos de Prehistoria y Arqueología 16.

(1991):'Tartessos”. Boletín de la Asociación Española de Amigos de la Arqueología, 30-31. Madrid. BERROCAL, L. (1989a): "El asentamiento céltico del castrejón de Capote (Higuera la Real, Badajoz)", Cuadernos de Prehistoria y Arqueología, 16.

_-(1989b): "Placas áureas de la Edad del Hierro en la Meseta Occidental", Trabajos de Prehistoria, 49. (1993). Los pueblos célticos del Suroeste de la Península Ibérica. Madrid.

(1995): "La Beturia. Definición y caracterización de un territorio prerromano". Cuadernos Emeritenses, 9.

BLANCO, A.(1987):” Destrucciones antiguas en el mundo ibérico y mediterráneo occidental”. Cuadernos de Prehistoria y Arqueología 13-14.

CAMPOS, J.M. y GÓMEZ, F. (1995):" El territorio onubense durante el Bronce Final", Tartessos, 25 años después. Jerez de la Frontera.

CANTO, A.M. (1979):" El acueducto romano de Itálica". Madrider Mitteilungen, 20.

—_(1995):" La Beturia Céltica. Introducción a su epigrafía". Cuadernos Emeritenses, 9. Mérida.

CUNHA SERRÃO, E. (1970):" As cerámicas de retícula bruñida das estaçoes arqueológicas espanholas e com ornatos bruñidos da Lapa do Fumo". Actas das I Jornadas Arqueológicas, I. Lisboa.

DOMERGUE, C. y ANDRADE, R.F.(1971):” Sondages 1967 et 1969 a Aljustrel (Portugal). Note preliminare". Conimbriga, 10. 
DROOP, J.P.(1925): "Excavations at Niebla in the province of Huelva, Spain". Annals of Archaeology and Anthropology, XII-3/4.

ENRÍQUEZ, J.J.(1990):" Sobre algunos poblados del Bronce Final de la provincia de Badajoz". Norba, 10.

—_ y RODRÍGUEZ, A. (1988):" Campaña de urgencia en la Sierra de la Martela (Segura de León, Badajoz)". Extremadura Arqueológica, I. Salamanca.

ESCACENA, J.L.(1989):" Los Turdetanos o la recuperación de la identidad perdida". Tartessos, Arqueología Protohistórica del Bajo Guadalquivir. Sabadell.

FERNÁNDEZ JURADO, J. (1985):" El poblamiento ibérico en Huelva". I Jornadas sobre el poblamiento ibérico. Jaén.

_ (1989): "Tejada la Vieja, ciudad protohistórica”. Huelva Arqueológica, IX.

FRAGOSO DA LIMA, J. (1960): “Castro de Ratinhos (Moura, Baixo Alentejo, Portugal)”. Zephyrvs, 11.

GARCÍA y BELLIDO (1993): "Las cecas libiofenicias”. VII Jornadas de Arqueología fenicio-púnica, Ibiza, 1992. Trabajos del Museo Arqueológico de Ibiza, 31.

GARCÍA IGLESIAS, I. (1971):" La Baeturia, un problema geográfico de la Hispania Antigua". Archivo Español de Arqueología, 44.

GÓMEZTOSCANO, F. (1997). Formas de ocupación del territorio durante los primeros siglos del Imilenio a.C.: El suroeste como marco de definición y contrastación. Huelva.

GÓMEZ, F., ÁLVAREZ, G. y BORJA, F. (1990):" Depósito funerario del Bronce en el travertino de Alájar (Huelva). Nuevas aportaciones". Cuadernos del Suroeste, 3.

GONZALO Y TARÍN, J.(1886): "Descripción física, geológica y minera de la provincia de Huelva". Memorias de la Comisión del Mapa Geológico de España. Madrid.

GUERRERO, O. (1996). Análisis y propuesta interpretativa del período turdetano en la Tierra Llana de Huelva. Trabajo de Tercer Ciclo (Inédito). Universidad de Huelva.

GUERRERO, O., CAMPOS, J.M. y PÉREZ, J.A. (e.p.):" La ocupación turdetana de la Tierra Llana de Huelva". II Congreso de Arqueología Peninsular. Zamora.

HURTADO, V. y GARCÍA, L.(1994): “Áreas funcionales en el poblado de la Edad del Bronce de El Trastejón (Zufre, Huelva)". Arqueología en el entorno del Bajo Guadiana. Sevilla.

JUBES, E. y CARBONELL, A.(1920): "Estudio geológico industrial de los yacimientos minerales del término de Encinasola y la Contienda de Moura". Boletín Oficial de Minas y Metalurgia, 34-39.

MARTÍN DE LA CRUZ, J.C.(1987): “El Llanete de los Moros, Montoro, Córdoba". (Excavaciones Arqueológicas en España, 15I). Madrid.

MAYET, F. y TAVARES, C.(1992):" Abul, um establecimiento orientalizante do seculo VII a.C. no Baixo Vale do Sado". Setubal Arqueológica, IX-X.

MONGE, A. (1992):" O povoado do Passo Alto. Excavaçoes de 1984". Archivo de Beja, III-2.

MONGE, A., FATIMA, M. y PEIXOTO, J.M. (1985):" O castelo Velho de Safara. Vestigios da pratica da metalurgia". Arqueología, 11. Porto.

MORAIS ARNAUD, J. (1979):" Coroa do Frade. fortificaçao do Bronze final dos arrededores de Evora. Excavaçoes de 1971/1972". Madrider Mitteilungen, 20.

PARREIRA, R. (1975):" O povoado da Idade do Bronce do Outeiro do Circo (Beringel/Beja)". Archivo de Beja, XXVIII-XXXII.

_ (1983):" O Cerro dos Castelos de S. Bras (Serpa)". O Arqueologo Portugues, IV-1.

PARREIRA, R. y MONGE, A. (1980):" Zu einigen Bronzezeitlichen Hohensidlungen in Sudportugal". Madrider Mitteilungen, 21. 
PAVÓN, I.(1994). Aproximación al estudio de la Edad del Bronce en la Cuenca Media del Guadiana. La Solana del Castillo de Alange. Salamanca.

PELLICER, M. (1989):" El Bronce Reciente y los inicios del Hierro en Andalucía Occidental". Tartessos, Arqueología protohistórica del Bajo Guadalquivir. Sabadell.

PÉREZ MACÍAS, J.A. (1985):" Introducción al Bronce Final en el Noroeste de la provincia de Huelva". Habis, 14.

(1986):" La ocupación prehistórica de la Peña de Arias Montano (Alájar, Huelva)". I Jornadas de Patrimonio de la Sierra de Huelva. Huelva.

_ (1991):" El poblado de Bronce Final de los Riscos del Castillo (Cabezas Rubias, Huelva)". Cuadernos del Suroeste, 3.

(1993a):" Cerámicas prerromanas de la Pasada del Abad (Rosal de la Frontera, Huelva)". Boletín de la Sociedad Española de Amigos de la Arqueología, 33.

—_ (1993b):" Poblados de la Edad del Hierro en la Sierra de Huelva. Orígenes e influencias en la formación de la Baeturia". Trabalhos de Antropologia e Etnologia, 33 (3-4).

- (1996): Metalurgia prerromana en la provincia de Huelva. Huelva.

y BUERO, M.(1986):"'Noticias preliminares sobre el Cerro de San Cristóbal". I Jornadas de Patrimonio de la Sierra de Huelva. Higuera de la Sierra.

— y BEDIA, J.(1996.):" Excavaciones de apoyo a la restauración de la Muralla de Niebla". Anuario Arqueológico de Andalucía/1992- III.

— y GÓMEZ, F. (e.p.):" Significación histórica del poblado de Castañuelo (Aracena, Huelva)". II Congreso de Arqueología Peninsular. Zamora.

RODRÍGUEZ DÍAZ, A. (1991): La Ermita de Belén (Zafra, Badajoz. Campaña de 1987). Mérida.

- (1995):" Territorio y etnias prerromanas en el Guadiana Medio. Aproximación arqueológica a la Beturia Túrdula". Cuadernos Emeritenses, 9.

— y BERROCAL, L.(1988):" Materiales de la Segunda Edad del Hierro del Cantamento de Pepina (Fregenal de la Sierra, Badajoz)". Cuadernos de Prehistoria y Arqueología, 15.

REGO, M., GUERRERO, O. y GÓMEZ, F. (1996):” Mértola, una ciudad mediterránea en el contexto de la Edad de Hierro del Bajo Guadiana". Actas de las I Jornadas Transfronterizas sobre la Contienda Hispano-Portuguesa, I. Badajoz.

RUIZ, M.M. y PÉREZ, J.A.(1989):" La presencia Orientalizante en la Faja Piritífera de Huelva". XIX Congreso Nacional de Arqueología. Zaragoza.

RUIZ-GÁLVEZ, M.(1995):"El significado de la Ría de Huelva en el contexto de las relaciones de intercambio y de las transformaciones producidas en la transición Bronce Final/Edad del Hierro". Ritos de Paso y Puntos de Paso. La Ría de Huelva en el mundo del Bronce Final Europeo. Complutum Extra, 5. Madrid.

RUIZ MATA, D. (1979):" El Bronce Final-fase inicial-en Andalucía Occidental, ensayo de definición de sus cerámicas". Archivo Español de Arqueología, 52.

_ (1993):" Los fenicios de época arcaica-siglos VIII/VII a.C.- en la Bahía de Cádiz. Estado de la cuestión". Estudos Orientais, IV.

_ (1995):" Las cerámicas del Bronce Final. Un soporte tipológico para delimitar el tiempo y el espacio tartésico". Tartessos, 25 años después. Jerez de la Frontera.

RUIZ, D., BLÁZQUEZ, J.M. y MARTÍN DE LA CRUZ, J.C.(1981): “ Excavaciones en el Cabezo de San Pedro (Huelva). Campaña de 1978". Huelva Arqueológica, $V$. Huelva.

RUIZ, A. y MOLINOS, M.(1993). Los iberos. Análisis arqueológico de un proceso histórico. Barcelona. 
SHEFTON, B.(1982):" Grecks and greek imports in the South of Iberian Peninsula. The archaeological evidence". Madrider Beitrage, 8. Mainz.

SOARES, J. y TAVARES, C. (1986):" Ocupaçao pre-romana de Setubal. Excavaçoes na Travessa dos Apostoles". I Encontro Nacional de Arqueología Urbana. Trabalhos de Arqueología, 03. Lisboa.

TAVARES, C. y SOARES, J. (1978):" Uma jazida do Bronce Final na Cerradinha (lagoa de Santo André, Santiago do Cacem)". Setubal Arqueológica, IV.

TAVARES, C., SOARES, J., BEIRAO, C., DIAS, L. y COELHO-SOARES,A.(1981):" Excavaçoes arqueológicas no Castelo do Alcacer do Sal (Campanha de 1979)". Setubal Arqueológica, VI-VII.

TOVAR, A. (1974). Iberische Landeskunde. Baden-Baden.

VARELA GOMES, M. (1990):" O Oriente no Occidente. Testemunhos iconográficos na proto-história do sul do Portugal. Smiting gods ou deuses ameaçadores". Estudos Orientais, I. Lisboa.

VIDAL, N. de la O (1996): Tejada la Nueva en el marco histórico de la Tierra Llana de Huelva. Análisis histórico-arqueológico. Trabajo de Investigación de Tercer Ciclo (Inédito). Universidad de Huelva. 